\title{
Role of vitamin D in iron metabolism, a pilot study
}

\author{
Uma Pandey $^{1 *}$, Hema Divakar ${ }^{2}$
}

\author{
${ }^{1}$ Department of Obstetrics \& Gynaecology, Institute of Medical Sciences, Banaras Hindu University, Varanasi, UP, \\ India \\ ${ }^{2}$ Department of Obstetrics \& Gynaecology, Divakars Hospitals, Bengaluru, Karnataka, India
}

Received: 18 August 2015

Revised: 09 September 2015

Accepted: 10 September 2015

\author{
*Correspondence: \\ Dr. Uma Pandey, \\ E-mail: uma.pandey2006@yahoo.com
}

Copyright: ( $)$ the author(s), publisher and licensee Medip Academy. This is an open-access article distributed under the terms of the Creative Commons Attribution Non-Commercial License, which permits unrestricted non-commercial use, distribution, and reproduction in any medium, provided the original work is properly cited.

\begin{abstract}
Background: The objective of the study was to evaluate the effect of Vit D \& Iron supplementation on Serum Hb level \&Vit D level as compared to Iron supplementation alone. To evaluate the percentage responders in terms of Haemoglobin to Iron supplementation when Vit D is added as compared to only Iron supplemented. Vitamin D Deficiency is very prevalent in our country due to many reasons; therefore we also wanted to assess how deficient they are?

Methods: Recruited pregnant mothers were with $25(\mathrm{OH}) \mathrm{D}<20 \mathrm{ng} / \mathrm{ml} \& \mathrm{Hb}=8-10 \mathrm{~g} / \mathrm{dl}$. Patients were randomized into groups using a computerized program. Group iron + Vitamin D : tablets containing fixed dose combination of vit $\mathrm{D}(1000 \mathrm{IU})+$ ferrous ascorbate $(100 \mathrm{mg}$ of elemental iron $)+$ folic acid $(1 \mathrm{mg})+$ vit $\mathrm{B}_{12}(7.5 \mathrm{mcg})(1 \mathrm{tab} / \mathrm{day})$ for 12 weeks. Group iron alone: tablets containing fixed dose combination of ferrous ascorbate (100 mg of elemental iron) + folic acid (1.1 mg) (1 tablet/day) for 12 weeks.

Results: There was no significant difference between the ages of patients of two groups. Parity and BMI were nearly same. Vit D level assessment at the recruitment in both groups is nearly same and also Hb level assessment at the recruitment in both groups is nearly same. The study shows that addition of Vitamin D to the Iron supplement does not increase the level of $\mathrm{Hb}$ any further as compared to the Iron administration alone.

Conclusions: This pilot study shows that administration of iron to Vitamin D does not influence the rise in haemoglobin level any greater than Iron administration alone. A larger sample size study is needed to prove this finding further.
\end{abstract}

Keywords: Anaemia, Vitamin D, Vitamin D deficiency, Pregnancy, Iron metabolism

\section{INTRODUCTION}

Vitamin D has a definite role to play in bone and mineral metabolism regulation. There are many other biologic functions in which Vitamin D is involved. They range from insulin production, muscle strengthening, and inhibition of renin synthesis, cellular proliferation and differentiation to immune system modulation. ${ }^{1-9}$

Vitamin D deficiency appears to be associated with anaemia as Vitamin D is suggested to have a role in erythropoiesis. Its exact mechanism is not known, but there are postulations. One postulation is that it modulates level of systemic cytokine production thus reduces inflammation and therefore anaemia of chronic disease. Another postulation is that there is high local concentrations of 1,25 hydroxyvitamin $\mathrm{D}$ in haematopoietic tissues which could be directly activating erythroid precursor cells in a paracrine fashion. ${ }^{10}$

There are certain clinical observations which also support Vitamin D role in red cell production. It has been demonstrated in bone marrow to affect bone marrow function. The active form of Vitamin D 
(1,25hydroxyvitamin D) level is many folds higher in bone marrow than plasma. ${ }^{11-13}$

In spite of the above data regarding Vitamin D level in bone marrow there aren't any conclusive evidence to suggest its role in erythropoiesis. Therefore, based on the above postulation and data we planned to carry out a pilot study comparing the rise in Haemoglobin level of two groups (one with Iron and the other with Iron and Vitamin D) in a randomised study which would support role of Vitamin D in rise of level of Haemoglobin.

Prevalence of Vitamin D was also found to quite high in a study conducted by Singh et al, Divakar Hospital, Bengaluru; keeping this in mind we chose a combination of Iron + Vitamin D- to make up for the concomitant deficiency.

\section{METHODS}

V-DIP study i.e. Vitamin D and Iron in Pregnancy Study was primarily aimed to study the effect of combined supplementation of vitamin D \& Iron as compared to Iron alone in pregnant women with Vitamin D deficiency with Iron Deficiency Anaemia. Institutional Ethics Committee had approved the project, of Institute of Medical Sciences, Banaras Hindu University, Varanasi.

The objective of the study was to evaluate the effect of Vit D \& Iron supplementation on Serum $\mathrm{Hb}$ level \&Vit D level as compared to Iron supplementation. To evaluate the percentage responders to Iron supplementation when Vit D is added as compared to only Iron supplemented.

Recruited pregnant mothers were with $25(\mathrm{OH})$ D $<20 \mathrm{ng} / \mathrm{ml} \& \mathrm{Hb}=8-10 \mathrm{~g} / \mathrm{dl}$. Patients were randomized into groups using a computerized program. Group Iron + Vitamin D : Tablets containing fixed dose combination of Vit D (1000 IU) + Ferrous Ascorbate (100mg of elemental iron) + Folic Acid (1mg) +Vit B12 (7.5mcg) (1tab/day) for 12 weeks. Group Iron alone: Tablets containing fixed dose combination of Ferrous Ascorbate (100mg of elemental Iron) + Folic acid (1.1mg) (1 tablet/day) for 12 weeks.
Inclusion Criteria were pregnant women of age 20-45 years, gestation age 12-22 weeks. All participant subjects should have clinically confirmed iron deficiency anaemia ( $\mathrm{Hb} 8-10 \mathrm{~g} / \mathrm{dl}$ ), all participant subjects should have 25 $(\mathrm{OH}) \mathrm{D}$ levels $\leq 20 \mathrm{ng} / \mathrm{ml}$, they are willing to follow the study protocol and patients have signed written informed consent.

Exclusion criteria were non-pregnant or lactating women, age $<20$ or $>45$ years, Hb level $<8$ or $>10$ g/dl, $25(\mathrm{OH}) \mathrm{D}$ levels $>20 \mathrm{ng} / \mathrm{ml}$, anaemia of any other cause (sickle, thalassemia, aplastic, hyperchromic etc.) and mothers on vitamins/mineral supplements.

The outcome measures were average rise in $\mathrm{Hb}$ levels: Study Arm (Group A) vs. Control Arm (Group B), average rise in $25(\mathrm{OH})$ D levels: Study Arm (Group A) vs. Control Arm (Group B), percentage patients responding to therapy: Study Arm (Group A) vs. Control Arm (Group B). Evaluated as $\geq 2 \mathrm{gm} / \mathrm{dl}$ rise in $\mathrm{Hb}$ levels.

\section{RESULTS}

In this pilot study there were 8 patients in Iron alone group and 12 pregnant mothers in Iron + Vitamin D group. The sample size for the study was calculated by using on line calculator from www.statstodo.com keeping $\alpha$ value 0.05 and power of study at $80 \%$ with average change in $\mathrm{Hb}$ level for $3 \mathrm{mg} / \mathrm{dl}$ with a variation of 2.5 $\mathrm{mg} / \mathrm{dl}$. The sample size hence obtained was 8 . Further it was increased to 12 keeping in mind the loss of followup. Hence 12 patients were undertaken in study for each group. At the end of study 4 patients of Iron group loss to follow-up hence results are based on 8 outcomes of Iron group and 12 outcomes of Iron + Vitamin D group. Patients were matched for their ages, parity and BMI.

Table-1 reveals that there was no significant difference between the ages of patients of two groups. Parity and BMI were nearly same. It is also clear from table-2 that the mean Vit D level as well as Hb level assessment at the recruitment in both groups was insignificant or nearly similar.

Table 1: Descriptive results of variables taken in study.

\begin{tabular}{|c|c|c|c|c|c|}
\hline \multirow{2}{*}{ Variable } & Group & $\mathbf{N}$ & Mean \pm SD. & \multicolumn{2}{|c|}{ Mann-Whitney U } \\
\hline & & & & $\mathrm{Z}$ & $\mathrm{p}$ value \\
\hline \multirow[t]{2}{*}{ Age } & Iron & 8 & $21.25 \pm 2.25$ & \multirow{2}{*}{1.633} & \multirow{2}{*}{0.103} \\
\hline & Iron + Vit. D & 12 & $23.58 \pm 3.26$ & & \\
\hline \multirow[t]{2}{*}{ Parity } & Iron & 8 & $2.00 \pm 1.31$ & \multirow{2}{*}{-} & \multirow{2}{*}{ - } \\
\hline & Iron + Vit. D & 12 & $2.00 \pm 1.13$ & & \\
\hline \multirow[t]{2}{*}{ Height } & Iron & 8 & $154.50 \pm 5.83$ & \multirow{2}{*}{0.234} & \multirow{2}{*}{0.815} \\
\hline & Iron + Vit. D & 12 & $154.33 \pm 3.99$ & & \\
\hline \multirow[t]{2}{*}{ Weight } & Iron & 8 & $51.50 \pm 2.98$ & \multirow{2}{*}{0.311} & \multirow{2}{*}{0.756} \\
\hline & Iron + Vit. D & 12 & $52.00 \pm 3.67$ & & \\
\hline \multirow[t]{2}{*}{ BMI } & Iron & 8 & $21.58 \pm 0.70$ & \multirow{2}{*}{0.54} & \multirow{2}{*}{0.589} \\
\hline & Iron + Vit. D & 12 & $21.82 \pm 1.13$ & & \\
\hline
\end{tabular}


Table 2: Vit D Levels of normal person (optimal), Insufficient and deficient patients.

\begin{tabular}{|c|c|c|c|c|c|c|c|}
\hline \multirow{2}{*}{ Group } & \multirow{2}{*}{$\mathbf{N}$} & Vit_D_pre & Vit_D_post & \multirow{2}{*}{$\begin{array}{l}\text { Wilcoxon } \\
\text { Signed } \\
\text { Ranks } \\
\text { Test. P } \\
\text { value }\end{array}$} & \multirow{2}{*}{$\begin{array}{l}\text { Ho_pre } \\
\text { Mean } \pm \text { SD. }\end{array}$} & Hb_post & \multirow{2}{*}{$\begin{array}{l}\text { Wilcoxon Signed } \\
\text { Ranks Test }\end{array}$} \\
\hline & & Mean \pm SD & Mean \pm SD & & & Mean \pm SD. & \\
\hline IRON & 8 & $\begin{array}{l}11.31 \pm 5.59 \\
\text { (A) }\end{array}$ & $\begin{array}{l}11.90 \pm 5.16 \\
\text { (B) }\end{array}$ & $\begin{array}{l}0.263 \\
\text { (A) vs (B) }\end{array}$ & $\begin{array}{l}9.15 \pm 0.52 \\
(\mathrm{E})\end{array}$ & $\begin{array}{l}11.18 \pm 1.28 \\
(\mathrm{~F})\end{array}$ & $\begin{array}{l}0.012 \\
(\mathrm{E}) \mathrm{vs}(\mathrm{F})\end{array}$ \\
\hline $\begin{array}{l}\text { Iron + Vit } \\
\text { D }\end{array}$ & 12 & $\begin{array}{l}9.95 \pm 5.00 \\
(\mathrm{C})\end{array}$ & $\begin{array}{l}17.38 \pm 3.62 \\
\text { (D) }\end{array}$ & $\begin{array}{l}0.002 \\
\text { (C) vs (D) }\end{array}$ & $\begin{array}{l}8.56 \pm 1.16 \\
(G)\end{array}$ & $\begin{array}{l}10.76 \pm 1.12 \\
(\mathrm{H})\end{array}$ & $\begin{array}{l}0.002 \\
(\mathrm{G}) \mathrm{vs}(\mathrm{H})\end{array}$ \\
\hline $\begin{array}{l}\text { Mann- } \\
\text { Whitney } \\
\text { Test }\end{array}$ & & $\begin{array}{l}(\mathrm{A}) \text { vs }(\mathrm{C}) \\
\text { Not } \\
\text { significant } \mathrm{P} \\
>0.05\end{array}$ & $\begin{array}{l}\text { (B) vs (D) } \\
\text { Significant } \\
\mathrm{p}=0.039\end{array}$ & & $\begin{array}{l}(\mathrm{E}) \text { vs }(\mathrm{G}) \\
\text { Not } \\
\text { significant } \\
\mathrm{P}>0.05\end{array}$ & $\begin{array}{l}(\mathrm{F}) \text { vs }(\mathrm{H}) \\
\text { Not significant } \\
\mathrm{p}=0.571\end{array}$ & \\
\hline
\end{tabular}

Table 3 shows the paired samples correlation between $\mathrm{Hb}$ rise of Iron alone and Iron + Vitamin D group. At 0.383 , the correlation between the baseline and three-month $\mathrm{Hb}$ levels is not statistically significant. Levels were lower overall, but the change was inconsistent across subjects. Several increased their levels, but several others either did not change or lowered their levels. On the other hand, the Pearson correlation between the baseline and threemonth $\mathrm{Hb}$ measurements is 0.9 , almost a perfect correlation. Unlike the Iron + Vit D group, all subjects in iron group increase $\mathrm{Hb}$ level and did so quite consistently. The table 4 shows the paired samples correlation between Vitamin D rise of Iron alone and Iron + Vitamin D. The Pearson correlation between the baseline and three-month Vitamin D level measurements , almost a perfect correlation and shows that Vitamin D level of all subjects increase and did so quite consistently. These findings are also justified by graphical representation. Prevalence of Vitamin D was also found to quite high in a study conducted by Singh et al, Divakar Hospital, Bengaluru. The V-DIP study investigated the level of $\mathrm{Hb}$ rise along with Vitamin $\mathrm{D}$ level rise in the group in which Iron along with Vitamin D was administered. The graph 1 shows the rise in $\mathrm{Hb}$ level and graph 2 shows the rise in Vitamin D level. Graph 3 and 4 are showing the level of rise of $\mathrm{Hb}$ and Vitamin in the Iron alone group.

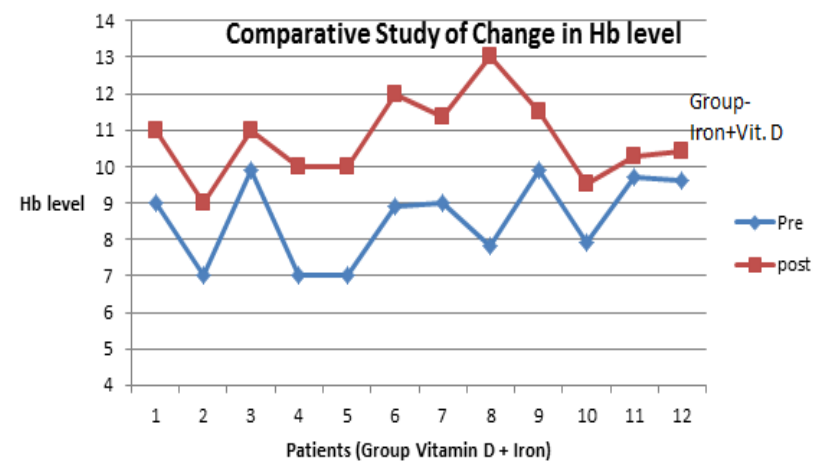

Figure 1: Rise in Hb level in Iron + Vitamin D group.

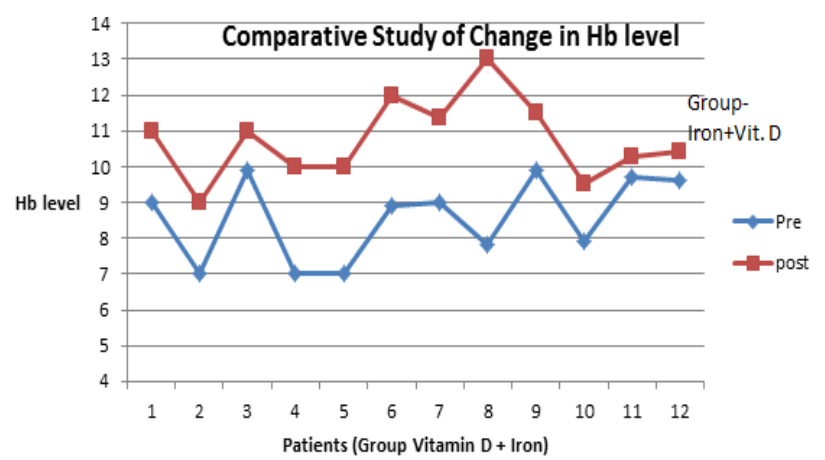

Figure 2: Rise in Vitamin D level in Iron + Vitamin D group.

Table 3: Paired simple correlations.

\begin{tabular}{|c|c|c|c|c|c|}
\hline \multicolumn{3}{|c|}{ Group_code } & $\mathbf{N}$ & Correlation & Significance \\
\hline Iron & $\begin{array}{l}\text { Pair } \\
1\end{array}$ & $\begin{array}{l}\mathrm{Hb} \\
\text { pre } \\
\& \\
\mathrm{Hb} \\
\text { post }\end{array}$ & 8 & 0.864 & 0.006 \\
\hline $\begin{array}{l}\text { Iron } \\
+ \\
\text { Vit. } \\
\text { D }\end{array}$ & $\begin{array}{l}\text { Pair } \\
1\end{array}$ & $\begin{array}{l}\mathrm{Hb} \\
\text { pre } \\
\& \\
\mathrm{Hb} \\
\text { post }\end{array}$ & 12 & 0.383 & 0.220 \\
\hline
\end{tabular}

In pre and post analysis of Iron + Vitamin D group it was found that there was significant increase in both the parameters studied i.e. Vitamin $\mathrm{D}$ and $\mathrm{Hb}$ however there was no significant change in the level of vitamin $D$ among the patients using iron only, though these patients noticed significant increase in $\mathrm{Hb}$ level. It was also tried to compare both groups on each of the parameters. The Mann-Whitney test was applied to know the significant difference in increase of vitamin $\mathrm{D}$ and $\mathrm{Hb}$ level between groups. Table 2 shows that level of vitamin D among the patients kept on Iron + Vitamin D increased significantly as compared to those kept on Iron only. However this 
type of difference was not noticed in case of $\mathrm{Hb}$. It infers that the combination of iron and vitamin $\mathrm{D}$ is helpful in managing both the parameters.

Table 4: Paired simple correlations.

\begin{tabular}{|c|c|c|c|c|c|}
\hline \multicolumn{3}{|l|}{ Group_code } & \multirow{2}{*}{$\begin{array}{l}\text { N } \\
8\end{array}$} & \multirow{2}{*}{$\begin{array}{l}\text { Correlation } \\
0.963\end{array}$} & \multirow{2}{*}{$\begin{array}{l}\text { Significance } \\
0.000\end{array}$} \\
\hline Iron & Pair 1 & $\begin{array}{l}\text { Vit_D_Pre \& } \\
\text { Vit_D_post }\end{array}$ & & & \\
\hline Iron + Vit. D & Pair 1 & $\begin{array}{l}\text { Vit_D_pre \& } \\
\text { Vit_D_post }\end{array}$ & 12 & 0.786 & 0.002 \\
\hline
\end{tabular}

Table 5: Vit D Levels of normal person (optimal), Insufficient and deficient patients.

\begin{tabular}{lll} 
Optimal Vit D Level & Insufficient & Deficient \\
$30-80$ & $20-29$ & $<20$ \\
\hline
\end{tabular}

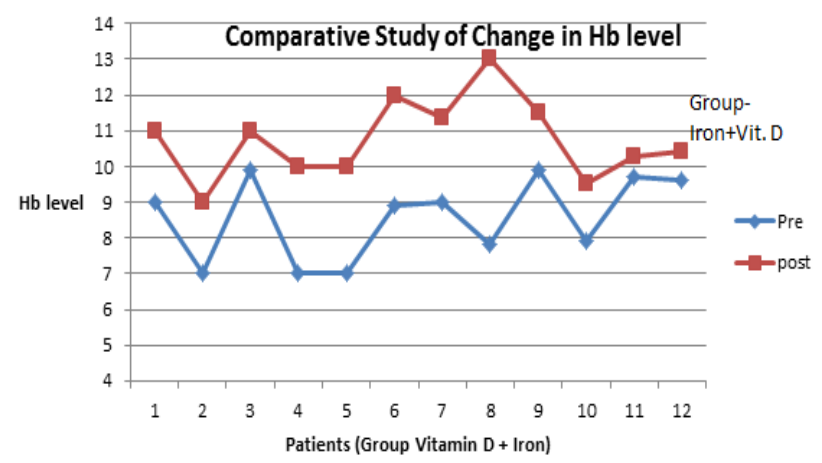

Figure 3: Rise in Hb level in Iron alone group.

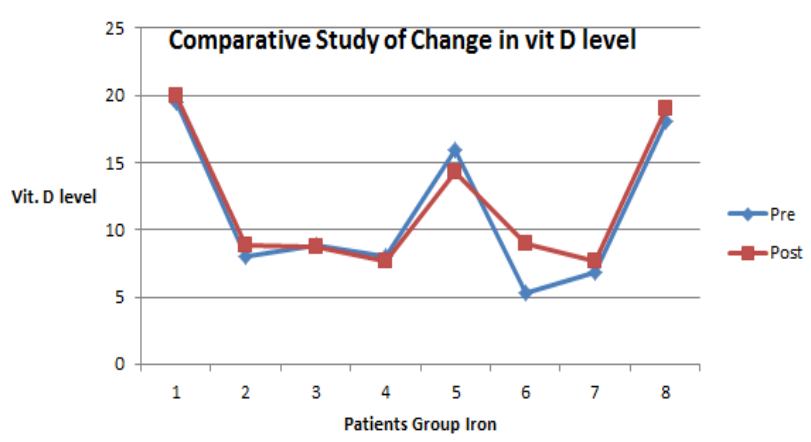

Figure 4: No rise in Vitamin D level in Iron alone group.

\section{DISCUSSION}

The study has compared the two groups (iron alone and Iron + Vitamin D group) and inferred that there is a comparative rise in vitamin $\mathrm{D}$ among pregnant patients if vitamin $\mathrm{D}$ is being given with iron. However there is no effect of iron on serum levels of vitamin D. Iron recommendation is found to be suitable for $\mathrm{Hb}$ rise but a composition of iron and vitamin $\mathrm{D}$ is useful in the management of women who is anaemic and Iron deficient both. In Indian context lack of vitamin D is also more prevalent because women because usually they aren't exposed to sun rays as they should have been which could result in lesser production of natural vitamin $\mathrm{D}$ in the skin of these women. The other factors which result in reduced Vitamin D levels are dark skin, obesity, elderly, vegetarian diet and increasing indoor activities.

In the study conducted by Singh and Divakar et al at Divakar's Hospital, Bengaluru showed that there were $18.7 \%$ of women who were severely deficient, $52.9 \%$ deficient, $19.3 \%$ insufficient and only $9 \%$ were optimum (table 5).

In the two groups (Iron alone and Iron + Vitamin D group) rise of both $\mathrm{Hb} \&$ Vitamin $\mathrm{D}$ level is significant in the Iron + Vitamin D group but the rise in Iron group is not i.e. Vitamin D does not influence rise in the level of $\mathrm{Hb}$ level. Therefore the abovementioned postulated hypothesis is not proved in this pilot study. There is need to do a larger sample study as at present there is a trend of easy availability of combination of Iron and Vitamin D and their prescription.

Although we are refuting the hypothesis by this pilot study but there is a possibility that Vitamin D deficient individuals are malnourished and are having chronic inflammatory condition due to underlying chronic infection. Therefore Vitamin D administration can have a positive influence on the level of $\mathrm{Hb}$ rise. There are both in vivo and in vitro studies that show that 1,25 hydroxyvitamin $\mathrm{D}$ reduces cytokine production. Therefore it reduces the inflammation and can have positive influence on $\mathrm{Hb}$ level rise. ${ }^{13}$

\section{CONCLUSIONS}

Use of vitamin D along with Iron has no significant effect on the rise of haemoglobin as compared to the Iron administration alone, but we need further study. Vitamin $\mathrm{D}$ deficiency is very prevalent in our country, almost $75 \%$ in a study done in BHU and almost $91 \%$ in a study done at Divakar's Hospital, Bengaluru. Therefore, we could add that by adding vitamin $\mathrm{D}$ to these women we would be helping pregnant mothers or general population in many other ways. It would be plausible to add the following: 
What was already known?

1. Vitamin D Deficiency is very high in India.

2. There is a possible role of Vitamin $\mathrm{D}$ on Iron Metabolism.

What this study adds:

1. The similar cohort had a significant $(91 \%)$ of Vitamin D Deficiency.

2. There is a significant rise in Vit D levels when tablets with Iron + Vit D were given.

3. The level of $\mathrm{Hb}$ rise is same in both groups- so adding Vit $\mathrm{D}$ has not compromised in rise in the $\mathrm{Hb}$ level.

4. The combination has offered an opportunity to correct the co-existing deficiency of Vitamin D.

5. Given the prevalence of Vitamin D deficiency, it may be worthwhile choosing a combination, rather than a standalone Iron supplement.

The study proves it was worthwhile to do so.

\section{ACKNOWLEDGEMENT}

The authors are thankful to Dr G P Singh, Department of Community Medicine, Institute of Medical Sciences, Banaras Hindu University, Varanasi, for help in statistics.

Funding: No funding sources

Conflict of interest: None declared

Ethical approval: The study was approved by the Institutional Ethics Committee

\section{REFERENCES}

1. Zittermann A. Vitamin D and disease prevention with special reference to cardiovascular disease. Prog Biophys Mol Biol. 2006;92:39-48.

2. Bischoff-Ferrari HA, Giovannucci E, Willet WC, Dietrich T, Dawson-Hughes B. Estimation of optimal serum concentration of 25-hydroxyvitamin D for multiple health outcomes. Am J Clin Nutr. 2006;84:18-28.

3. Holick MF, Garabedian M. Primer on the metabolic bone diseases and disorders of mineral metabolism, $6^{\text {th }}$ Edn. American Society for Bone and Mineral Research, Washington, DC, 2006.

4. Bouillon R, Sarandeses LA, Allewaert K, Zhao J, Mascarenes JL, Mourino A, et al. Biologic activity of dihydroxylated 19-nor-(pre)vitamin D3. J Bone miner Res. 1993;8:1009-015.

5. DeLuca HF. Overview of general physiologic features and functions of vitamin D. Am J Clin Nutr 2004; 80: 1689S-1696S.

6. Dusso A, Brown A, Slatopolsky E. Extrarenal production of calcitriol. Semin Nephrol. 1994;14:144-55.

7. Penna G, Roncari A, Amuchastegui S, Daniel KC, Berti E, Colonna M, Adorini, Expression of the inhibitory receptors ILT3 on dendritic cells is dispensable for induction of CD4+ Foxp3+ regulatory $\mathrm{T}$ cells by 1,25-dihydroxy vitamin $\mathrm{D} 3$. 2005;106:3490-7.

8. Li YC Vitamin D regulation of the renin-angiotensin system. J Cell Biochem. 2003;88:327-31.

9. Chiu KC, Chu A, Go VL, Saad MF Hypovitaminosis D is associated with insulin resistance and beta cell dysfunction. Am J Clin Nutr. 2004;79:820-5.

10. Blazsek I, Farabos C, Quittet P, Labat ML, Bringuier AF, Triana BK, Machover D, Reynes M, Misset JL. Bone marrow stromal cell defects and 1 alpha, 25dihydroxyvitamin D3 deficiency underlying human myeloid leukaemias. Cancer Detect Prev. 1996;20:31-2.

11. Reichel H, Koeffler HP, Norman AW. The role of vitamin $\mathrm{D}$ endocrine system in health and disease. $\mathrm{N}$ Eng J Med. 1989;320:980-91.

12. Norman W. Minireview; vitamin D receptor: new assignments for an already busy receptor. Endocrinology. 2006;147(12):5542-8.

13. Blazsek I, Farabos C, Quittet P, Labat ML, Bringuier AF, Triana BK, Machover D, Reynes M, Misset JL. Bone marrow stromal cell defects and 1 alpha, 25dihydroxyvitamin D3 deficiency underlying human myeloid leukemias. Cancer Detect Prev. 1996;20:3142.

Cite this article as: Pandey U, Divakar H. Role of Vitamin D in iron metabolism, a pilot study. Int J Reprod Contracept Obstet Gynecol 2015;4:1494-8. 